\title{
O PERCURSO E O LUGAR DE FRIEDRICH SCHLEIERMACHER NA FORMAÇÃO DO ROMANTISMO ALEMÃO
}

\section{Vitor Gomes da SILVA *}

* Mestre e doutorando em Ciência da Religião pela UFJF, Licenciado em Filosofia (UFJF) e Professor de Filosofia do Instituto Federal de Educação, Ciência e Tecnologia de Rondônia (IFRO). E-mail: vitor.gomes@ifro.edu.br.

Artigo submetido em fevereiro/2015 e aceito em julho/2015

DOI: http://dx.doi.org/10.15628/dialektike.2015.2771

\section{RESUMO}

O texto que se segue investigará a trajetória e o lugar de Schleiermacher no romantismo alemão. Após a apresentação de algumas questões filosóficas caras ao romantismo - principalmente em seus primeiros momentos - exemplificar-se-á o trajeto de Schleiermacher e Schlegel na concreção do programa romântico. Por fim, papel de Schleiermacher nos primeiros anos do romantismo. Teria sido Schleiermacher um protagonista na formação do movimento romântico ou apenas um autor que, assim como qualquer coadjuvante, teria extraído apenas algumas intuições básicas do movimento? destacar-se-á a tentativa de se mensurar qual o

PALAVRAS-CHAVE: Infinito. Intuição. Religião. Romantismo.

\begin{abstract}
The following text evaluates the path and Finally, the attempt of measuring the role of emplacement of Schleiermacher in German Schleiermacher in the early years of Romanticism Romanticism. After presenting some will be highlighted. Would have bee philosophical inquiries major to Roamticism - Schleiermacher a leading figure in the especially in its first moments - it will be Romanticism movement or just na author who, exemplify the Schleiermacher and Schlegel like any other coadjutant, would have excerpted pathways in Romanticism's establishment. just some basic movement perceptions.
\end{abstract}

KEYWORDS: Infinite. Intuition. Religion. Romanticism.

\section{ALGUNS PRESSUPOSTOS FILOSÓFICOS BÁSICOS DO ROMANTISMO}

O termo "romântico" foi lançado decisivamente sobre o ambiente cultural da época através do pensamento de Friedrich Schlegel. Foi em 1798, no fragmento 116 do Athenaeum, que Schlegel definiu o cerne do movimento através da sua concepção de romantische Poesie [poesia romântica]. Esta concepção se instaurou, inicialmente, como termo clássico de 
designação de um ideal literário e, posteriormente, de um movimento filosófico, cultural, social, estético etc ${ }^{1}$.

Segundo Frederick Beiser, o conceito de romantische Poesie é o melhor caminho para se começar a entender os autores da Frühromantik [primeiro romantismo]. Este conceito não designa simplesmente uma forma de literatura em particular, mas capta o ideal estético geral do romantismo independentemente de sua expressão se dar através da pintura, da escultura, da literatura ou da filosofia. O caráter revolucionário do movimento é acentuado, visto que ele “[...] exigiu que nós transformássemos não somente a literatura e o criticismo, mas todas as artes e ciências; e ele também insistiu para que nós derrubássemos as barreiras entre a arte e a vida, a fim de que o próprio mundo se tornasse "romantizado""2.

Como podemos perceber, há um processo no qual Schlegel generaliza o conceito de poesia romântica. Tanto a literatura (poesia) como as artes (quadros e esculturas) e as ciências (ciência e filosofia) devem ser abarcadas pelo invólucro romântico, ou melhor, devem ser "romantizadas". Uma primeira generalização aparece no campo da própria literatura. Uma das características fundamentais da literatura moderna em detrimento da clássica é que ela é mais eclética e, conseqüentemente, abrange uma gama mais ampla de estilos e gêneros. Para Schlegel, o aparente caos da literatura moderna não é nada mais nada menos do que a busca incessante por uma unidade que foi dada somente aos gregos; e que deve ser recuperada por meio de uma nova atividade criativa do homem ${ }^{3}$.

Ao definirmos a generalização do conceito de poesia romântica em termos de ecletismo literário, estamos ainda exclusivamente em um único e determinado campo. Contudo, se a romantische Poesie é eclética e possui inúmeras formas de se manifestar na literatura, torna-se difícil classificá-la seguindo apenas regras lingüísticas. Portanto, outra forma de se descrever a poesia romântica seria apelar para os valores morais e estéticos que o conceito oferece. De acordo com Beiser, é justamente este expediente que Schlegel utiliza em suas notas literárias e filosóficas por volta de 1797, alguns meses antes da composição dos Athenäumsfragmente: "Ele [Schlegel] define [as obras românticas] em termos de suas qualidades morais, se são éticas ou políticas; ou em termos de suas qualidades estéticas, se

\footnotetext{
${ }^{1}$ Arthur O. LOVEJOY. On the Meaning of 'Romantic' in Early German Romanticism. Modern Language Notes. The Johns Hopkins University Press, vol. 31, n. 7, 1916, p. 385-396.

${ }^{2}$ Frederick C. BEISER. The Romantic Imperative: The Concept of Early German Romanticism. Cambridge, Massachusetts; London: Harvard University Press, 2003, p. 8-9.

${ }^{3}$ Frederick C. BEISER. The Romantic Imperative: The Concept of Early German Romanticism, p. 12.

Dialektiké. Ano 2, v. 2, out 2015, p. 89-103 | Revista de Filosofia 
são imaginativas, imitativas e sentimentais"4. O alargamento dos quesitos para se definir a romantische Poesie possibilitou que todo tipo de manifestação artística pudesse ter uma classificação singular. A ampliação do critério deste conceito central para o romantismo também possibilitou a seguinte questão: o que faz uma qualidade estética como, por exemplo, a imaginação, ser atributo apenas da arte literária?

A atitude de Schlegel foi verdadeiramente revolucionária, do ponto de vista filosófico, quando ele estende o conceito de romantische Poesie às ciências ${ }^{5}$. Se o que é "romântico" é determinado por qualidades estéticas e morais, então não há razão para que a concepção da poesia romântica esteja limitada ao campo artístico em geral. Com isso, a tendência que separava artes e ciências em compartimentos estanques foi se desintegrando. Concomitantemente, a atitude anti-fundacionalista ${ }^{6}$ típica dos românticos contribuía para a derrocada de um ideal clássico de razão; que pensava filosofia, ética, estética etc. dentro do rigor científico. De fato, os românticos não abandonaram a razão, mas abandonaram a ideia de que a filosofia começa com qualquer princípio único. E quanto mais a filosofia se afastava da ciência, mais ela se aproximava do espírito artístico: "Este foi, de fato, o ideal de toda Naturphilosophie: a exposição poética da ciência"7. A Freiheitschrift de Schelling ${ }^{8}$ pode ser

\footnotetext{
${ }^{4}$ Frederick C. BEISER. The Romantic Imperative: The Concept of Early German Romanticism, p. 13:

${ }^{5}$ Em relação ao significado de ciência presente aqui, Dreher afirma: "Tanto o século dezessete como o século dezoito foram particularmente prolíficos em ternos de publicações que tratam com o escopo e a natureza da 'ciência' (Wissenschaft). A melhor tradução do termo é provavelmente 'conhecimento sistemático, rigoroso'. Isto deve ser, não somente, mas em grande medida, equiparado ao conhecimento filosófico [...]”. (DREHER, Luis Henrique. Metaphors of light: Philipp K. Marheineke's Method and the Ongoing Program of Mediation Theology. Bern; Berlin; Frankfurt/M; New York; Paris; Wien: Peter Lang, 1998, p. 37.)

${ }^{6}$ Manfred Frank classifica os autores românticos através de um compromisso filosófico central que todos compartilham, a saber, o anti-fundacionalismo epistemológico, o ceticismo em relação aos primeiros princípios em filosofia. Como exemplo clássico de uma filosofia fundacional temos a filosofia fichteana; Fichte está seguro de que a filosofia deve começar com um princípio único, isto é, o sujeito. Elizabeth Millán-Zaibert, tradutora da obra que aqui se segue de Manfred Frank para o inglês, afirma o seguinte: "Para Fichte, a estrutura do Eu e sua suficiência para pôr o Não-Eu gerou um sistema de conhecimento que foi o resultado da certeza em relação aos primordiais. O Eu primordial de Fichte não depende, de qualquer maneira, do que se segue ou do que é deduzido dele. Portanto, nós podemos entender o escopo total do conhecimento através de uma análise de suas partes". (Elizabeth MILLÁN-ZAIBERT. What is Early German Romanticism? In: Manfred FRANK. The Philosophical Foundations of Early German Romanticism. Trad: Elizabeth Millán-Zaibert. New York: State University of New York Press, [s.d], p. 9.

${ }^{7}$ Frederick C. BEISER. The Romantic Imperative: The Concept of Early German Romanticism, p. 14.

${ }^{8}$ Ao falar sobre o conceito e a possibilidade do mal nessa obra, Schelling afirma que parte de uma distinção feita pela chamada filosofia da natureza, isto é, aquela que diferencia entre o ser como existente e o ser como fundamento da existência. Segundo esse pensamento, Deus tem em si mesmo o fundamento da sua própria existência. Este fundamento não pode ser tomado como um simples conceito, ele é a natureza em Deus, algo que é inseparável deste, mas, contudo, diferente. Aqui, Schelling descarta a possibilidade da contradição desta distinção, pois a relação entre o fundamento natural e Deus como espírito não se dá regulada por uma anterioridade temporal ou essencial. O fundamento que está em Deus precede-o já que o cria, mas não existiria caso Deus não fosse ato. Schelling afirma que todo esse complexo processo ocorre como um "golpe de magia". (Friedrich W. J. SCHELLING. Investigações filosóficas sobre a essência da liberdade humana e os assuntos com
} 
citada como exemplo dessa nova forma de exposição de um novo programa, o da "romantização" do mundo.

Os românticos efetivamente contemplavam visões e não simplesmente tinham pressentimento delas. Tal contemplar não se dava em sua inteireza mediante apenas ao puro vivenciar das emoções, este processo era inerente a outro, qual seja, ao submeter tais emoções a análises. Em suma, os românticos refletiam sobre seus instintos. Os Stürmer und Dränger, por seu turno, não ousavam dar um nome à emoção, pois o nome era algo vazio que, em muitas vezes, anulava a inspiração divina ou intuitiva. O indivíduo passa rapidamente por uma emoção singular e resigna-se com receio de interpretá-la ${ }^{9}$. A tendência em analisar as emoções fez o romantismo muito produtivo em dois campos, a saber: a contemplação da arte e a compreensão da religião.

A cultura da época, portanto, tinha sido possuída não só por artistas, mas por pensadores que refletiam sobre a sua própria arte. Schleiermacher, segundo Walzel, foi um destes pensadores que compreendeu de forma penetrante o seu próprio empreendimento, ele era capaz de compreender a essência da religião, pois “" [...] tinha a habilidade, em uma forma romântica verdadeira, para transformar a emoção em conceitos e para compreender sua peculiaridade e sua relação antitética em relação à atividade intelectual" ${ }^{10}$. Schleiermacher pode ser tomado aqui como exemplo do artista/pensador romântico, pois recorre a uma análise das emoções, mas procura não vacilar diante delas e nem degenerar em um racionalismo puro.

Foi por esse motivo que o romantismo pôde estabelecer um ponto de contato com $\mathrm{Jacobi}^{11}$. Schleiermacher foi o romântico que mais teve contato com o filósofo da fé. Ora, este contato se deu, não por acaso, em um campo no qual os românticos reservaram apenas para as emoções ou intuições, o campo da religião. De fato, Jacobi foi decisivo para o alvorecer do novo ponto de vista romântico, principalmente no tangente ao aspecto cognitivo da realidade ${ }^{12}$, que não se situa em um ponto único, estando sempre em constante mudança: “O

ela relacionados. Trad: Carlos Morujão. Lisboa: Edições 70, 1993, p. 97).

${ }^{9}$ Oskar WALZEL. German Romanticism. Trad: Alma Elise Lussky. New York: Capricon Books, 1966, p. 12.

${ }^{10}$ Oskar WALZEL. German Romanticism, p. 13.

${ }^{11}$ Alexander W. CRAWFORD. The Philosophy of F.H. Jacobi. London: Macmillan \& Co, 1905, p. 15.

12 Resumidamente, podemos apresentar o argumento de Jacobi da seguinte maneira: Fatos tornam-se conhecidos e são formulados em proposições (juízo kantiano). Se um state of affairs é um fato e, portanto, conhecido, a afirmação correspondente ao fato deve ser condicionada por algo mais, que serve para justificá-lo. Assim, esta afirmação deve ser condicionada por outra, e esta por outra ad infinitum. Se todas as nossas crenças são condicionadas por outras crenças nós nunca chegamos ao conhecimento do incondicionado. Se continuarmos neste raciocínio, perceberemos que todas as proposições são válidas apenas condicionalmente. Mas, se nós 
ceticismo dos primeiros românticos alemães é direcionado precisamente contra um programa de fundamentos absolutos. Eles questionam se há um conhecimento imediato e encontram no apelo à fé de Jacobi uma solução indefensável ao problema do caráter incognoscível do Absoluto. De acordo com a posição romântica, nosso conhecimento é situado em uma progressão infinita e não tem um fundamento firme, absoluto"13.

Do ponto de vista filosófico, é justamente esse ceticismo que busca gerar uma alternativa ao pensamento transcendental de Kant, Reinhold e Fichte. O antifundacionalismo dos românticos é a chave principal para compreendermos seu significado filosófico. Assim, para exemplificarmos esta importante atitude romântica, iremos analisar o conceito de ironia de Schlegel e a concepção da vida do Todo em Schleiermacher. Veremos que a influência mútua entre, pelo menos, dois princípios opostos, é o diagnóstico apresentado por ambos os autores no intuito de captar a realidade que não está fixada em algo, mas sim envolvida em uma constante mudança.

\section{A ESTRUTURA BIPOLAR DO CONCEITO DE IRONIA DE FRIEDRICH SCHLEGEL E A CONCEPÇÃO DA VIDA DO TODO APRESENTADA POR SCHLEIERMACHER NOS DISCURSOS}

Sabemos que, como nota Richard Crouter ${ }^{14}$, o tema da polaridade é um elemento típico do século XVIII, seja na literatura, nas artes, na filosofia etc. Nossa intenção é exemplificar, por meio de tal tema, a influência mútua entre Schlegel e Schleiermacher e a contribuição de ambos para a consolidação do romantismo. Schleiermacher e Schlegel freqüentaram a casa de Henriette Herz, um dos centros da sociedade berlinense. Schleiermacher interessou-se pela versatilidade e pela personalidade provocativa de Schlegel, surgindo daí uma amizade e o começo de contribuições filosóficas e literárias ${ }^{15}$. Em 1797 eles chegaram a dividir um apartamento. Um ano depois, Schlegel apresenta seus primeiros

afirmarmos a existência do Absoluto, isso significa que pelo menos uma proposição não é válida condicionalmente, mas incondicionalmente: "Jacobi chamou o conhecimento que é expresso em uma proposição incondicional, 'sentimento' (ou fé [Glaube])". (Manfred FRANK. The Philosophical Foundations of Early German Romanticism, p. 34.)

${ }^{13}$ Manfred FRANK. The Philosophical Foundations of Early German Romanticism, p. 34.

${ }^{14}$ Richard CROUTER. Introduction. In: Friedrich D. E. SCHLEIERMACHER On Religion: Speeches to its Cultured Despisers. Trad: Richard Crouter. Cambridge: Press Syndicate of the University of Cambridge, 1996, p. 5.

15 Martin REDEKER. Schleiermacher: Life and Thought. Trad: John Wallhauser. Philadelphia: Fortress Press, 1973, p. 30.

Dialektiké. Ano 2, v. 2, out 2015, p. 89-103 | Revista de Filosofia 
apontamentos sobre a ironia nos fragmentos do Athenaeum e nos de Lyceum, enquanto Schleiermacher, no mesmo ano, inicia seu projeto de escrever os Discursos.

$\mathrm{Na}$ esteira da íntima convivência entre ambos durante o período de Schleiermacher em Berlim, Schlegel e Schleiermacher concordavam com a ideia de que o universal e o particular, a unidade e o caos, o indivíduo e o Todo deviam se comunicar de alguma maneira. Concordavam também que a razão não seria a protagonista neste processo, mas apenas mais um elemento entre tantos outros. Ambos tinham apreço em relação à concepção que valoriza os aspectos particulares do Todo, ou seja, a vida terrena. Contudo, segundo Forstman, Schlegel ousou elevar o homem ao patamar dos deuses e, durante o período da escrita dos Discursos por Schleiermacher, tentou levar o amigo a uma órbita mais elevada. Mas o sentido da limitação terrena impediu Schleiermacher: "Schlegel pensou que ele e Schleiermacher fossem amantes dos santuários supremos, mas o santuário de Schleiermacher foi muitíssimo mais mundano do que o de Schlegel"16.

Como vimos, os românticos de uma forma geral eram céticos em relação ao programa fundacional. Ao passo que eles não abandonaram o conhecimento, ao mesmo tempo sabiam da infinidade desta tarefa. Eles perceberam que o seu anseio pelo infinito estava destinado a ser apenas anseio. A ironia romântica emergiu enquanto explicação de tal condição; ela aponta para o fato de que o indivíduo romântico estava consciente "[...] da antítese irreconciliável entre suas necessidades metafísicas e sua realização" ${ }^{17}$. Contudo, esta situação paradoxal na qual o homem se encontra, esse pairar entre duas situações irreconciliáveis é vista como o genuíno papel do homem no mundo: "Ironia é a forma do paradoxo. Paradoxo é tudo que é simultaneamente bom e grandioso"18.

O conceito de ironia de Schlegel pode ser pensado em termos de combinação, como por exemplo, uma combinação entre particular e universal. Nela cada um dos membros se expande e se limita em relação à atividade do outro. As raízes da ironia de Schlegel estão, pois, na consciência dos limites:

Ela [a ironia] oscila entre as polaridades do entendimento e do não entendimento, das conceitualidades gerais e das particularidades infinitas do caos. Com cada um destes agindo como fator limitador em relação ao outro, nenhum ponto de

\footnotetext{
${ }^{16}$ Jack FORSTMAN. A Romantic Triangle: Schleiermacher and Early German Romanticism. Montana: Scholars Press, 1977, p. 90.

${ }^{17}$ Oskar WALZEL. German Romanticism. Trad: Alma Elise Lussky. New York: Capricon Books, 1966.

${ }^{18}$ Friedrich SCHLEGEL. Philosophical Fragments. Trad: Peter Firchow. Minneapolis; London: University of Minnesota Press, 1998, p. 06.
}

Dialektiké. Ano 2, v. 2, out 2015, p. 89-103 | Revista de Filosofia 
conhecimento absoluto está disponível para a pessoa. Paira-se no meio, por assim dizer, esforça-se sempre por um novo conhecimento e por um novo entendimento, mas nunca se está apto para alcançar o Todo, nem como uma generalidade que tudo abrange e nem como uma massa infinita de particulares ${ }^{19}$.

Neste quadro, a ironia seria uma espécie de contentamento interno. Se, por um lado, o conhecimento carrega toda a seriedade que lhe é peculiar, por outro, lança-se um olhar jocoso sobre a infinidade da tarefa. São justamente essas combinações que devem ser conectadas, mas nunca completamente resolvidas.

As combinações entre seriedade e divertimento, entre zelo e gracejo, entre o respeito ao conhecimento científico e ao aspecto intuitivo do homem são as que fundamentam a essência da ironia no pensamento de Schlegel $^{20}$.

Neste tipo de ironia tudo deveria ser jocoso e sério, sinceramente aberto e profundamente escondido. Ela origina-se na união do savoir vivre e do espírito científico na conjunção de uma filosofia completamente instintiva e completamente consciente. Ela compreende e desperta um sentimento de antagonismo indissolúvel entre $\mathrm{o}$ absoluto e o relativo, entre a impossibilidade e a necessidade de uma completa comunicação ${ }^{21}$.

Esta essência não tolera mais a ideia de uma harmonia que abarca tanto as particularidades quanto as generalizações; ela entende que quando se afirma algo geral, a particularidade é violada em sua especificidade. Mas, para os românticos, o lugar da vida do mundo é no particular; o que significa dizer que eles estavam perfeitamente conscientes das diferenças e das individualidades. Foi por esse motivo que a amizade se apresentou como valor fundamental para estes homens, pois ela está focada sobre a individualidade, sobre o reconhecimento da particularidade do outro ${ }^{22}$.

A concepção irônica da realidade valoriza o mundo em toda a sua complexidade: “ $O$ maior efeito da nova consciência do infinito ou do caos das individualidades foi uma sabedoria mais elevada da completude e da riqueza da vida, mas o interesse de Schlegel nas variações infinitas foi contrabalanceado pela ênfase repetida em reunir as coisas em combinações muito perspicazes"23. Tais combinações são acompanhadas pelo ego [wit], ele é uma espécie de poder pelo qual o ser humano percebe as combinações. Segundo Forstman,

19 Jack FORSTMAN. A Romantic Triangle: Schleiermacher and Early German Romanticism, p. 02-03.

${ }^{20}$ Jack FORSTMAN. A Romantic Triangle: Schleiermacher and Early German Romanticism, p.03.

${ }^{21}$ Friedrich SCHLEGEL. Philosophical Fragments, p.13.

22 Jack FORSTMAN. A Romantic Triangle: Schleiermacher and Early German Romanticism, p.04.

${ }^{23}$ Jack FORSTMAN. A Romantic Triangle: Schleiermacher and Early German Romanticism, p.05. 
Schlegel o conceitua de "sociabilidade lógica", pois assim como uma pessoa deseja se unir a outras em novas e diversificadas maneiras; o ego, "[...] essência de um espírito combinante"24, busca unir ideias. Em suma, o paradoxo em que a situação humana está inserida necessita de um acompanhamento, algo que possa mediar a relação entre dois opostos: "A situação humana é irônica porque ela ocorre entre o caos infinito de um lado e o impulso em direção a unidade infinita de outro, não sendo nenhum lado alcançável. O ego, de acordo com Schlegel, é um agente fundamental nesta vida, no meio e, conseqüentemente, um indispensável acompanhamento da ironia" ${ }^{25}$.

Forstman indica que Schlegel estava determinado a realizar vários tipos de combinações e conexões e, como muitos no século XIX, utilizou-se de metáforas extraídas da ciência natural. As mecânicas são as combinações mais baixas, as mais altas são as químicas, uma combinação ainda mais alta é a união orgânica. Neste último tipo de combinação, o Todo vivo ocorre. A metáfora do orgânico tornou-se a maior metáfora para os românticos de todos os países ${ }^{26}$ : "O traço distintivo da concepção orgânica é o desejo de compreender cada fenômeno como um todo. Concentrar-se na ideia do todo, da unidade, independentemente se o mundo em si ou apenas uma parte dele está sendo estudada e avaliada" ${ }^{27}$. No pensamento de Schlegel, o conhecimento e a avaliação da unidade orgânica fizeram com que ele considerasse não só uma obra como um todo orgânico, mas tudo que estivesse relacionado à arte em si como uma unidade orgânica. $\mathrm{O}$ desejo de conceber o trabalho de arte como um todo orgânico vem do desejo metafísico de Schlegel. Ele “[...] veria uma obra de arte em suas inter-relações mais profundas e tornar-se-ia ciente da unidade que prevalece no meio da sua [obra de arte] diversidade. Da obra individual de arte ele procede logicamente à arte enquanto todo" 28 . Schlegel afirmou para o Universo as mesmas qualidades que ele aplicou à "arte enquanto todo". Desta maneira, ele chega a uma concepção que funciona como pano de fundo nos Discursos de Schleiermacher, a concepção organicista do jogo contínuo de forças opostas.

Já nas primeiras páginas do primeiro discurso, Schleiermacher apresenta a concepção de que o Todo se expressa incessantemente em variadas partes. Em todo momento, a vida funde dois elementos diversos, que possuem cada um a sua singularidade; que são opostos um ao outro, mas que são reciprocamente dependentes: "Toda vida é somente o resultado de uma

\footnotetext{
24 Jack FORSTMAN. A Romantic Triangle: Schleiermacher and Early German Romanticism, p.05.

25 Jack FORSTMAN. A Romantic Triangle: Schleiermacher and Early German Romanticism, p.06-07.

${ }^{26}$ Jack FORSTMAN. A Romantic Triangle: Schleiermacher and Early German Romanticism, p. 06.

${ }^{27}$ Oskar WALZEL. German Romanticism, p. 56-57.

${ }^{28}$ Oskar WALZEL. German Romanticism, p. 58.
} 
repulsão e de uma apropriação contínuas; tudo tem seu ser determinado somente em virtude do caminho no qual ela, de forma singular, combina e retém as duas forças primárias da natureza: a sedenta atração e a expansão do eu ativo e vivo" ${ }^{29}$. Do ponto de vista antropológico, Schleiermacher entende que o homem quer ser ele mesmo, quer ser individual, quer sugar o quanto possível do mundo para dentro de si. O homem quer possuir. Por outro lado, o homem permanece temeroso em permanecer sozinho perante o Todo e, assim, deseja tornar-se parte de algo maior. O homem quer ser possuído.

Há momentos em que uma tendência é quase completamente bloqueada pela outra, mas, a beleza da vida se dá na riqueza de combinações possíveis que efetivamente existem na humanidade. Não é por acaso que Schleiermacher afirma que "Cada alma humana [...] é meramente um produto de impulsos opostos" ${ }^{30}$. Os extremos são deficientes. Aquele que permanece no mundo somente envolto em particularidades nunca ultrapassará a consciência do individual. ${ }^{31}$ Já aquele que somente busca o Todo perderá as diferenças e particularidades do mundo, pois se encontra circundado por meros ideais abstratos.

De acordo com Schleiermacher, existem momentos nos quais os opostos estão quase em perfeita harmonia ${ }^{32}$. Todavia, essa harmonia não é sinônima de algo estático, ela representa um novo rearranjo das forças opostas no Todo. Este se faz perceptível somente por aqueles indivíduos que possuem tal combinação harmônica dentro de si e, portanto, conseguem expressá-la. Schleiermacher considera como sua tarefa nos Discursos seduzir todos que possuam o mesmo dom de se expressar, de restituir a religião em toda a sua

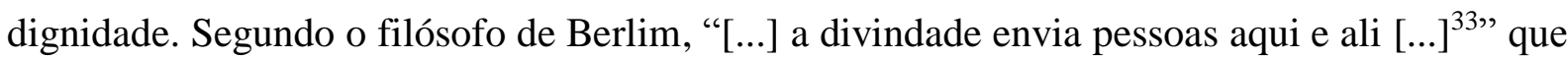
são como que mediadores entre o limitado e o ilimitado. $\mathrm{O}$ papel desses mediadores é trazer unidade e harmonia para um contexto marcado por uma estrutura bipolar.

Como vimos, a oposição das forças é o que define uma vida. Assim, os mediadores, por serem como que "embaixadores de Deus" ${ }^{34}$, possuem o poder não só de identificar tal oposição em seu próprio interior, mas também de comunicá-la harmoniosamente para aqueles que não possuem tal dom comunicativo. Schleiermacher expressará, como mediador que

\footnotetext{
29 Friedrich D. E. SCHLEIERMACHER . On Religion: Speeches to its Cultured Despisers. Trad: Richard Crouter. Cambridge: Press Syndicate of the University of Cambridge, 1996, p. 05.

${ }^{30}$ Friedrich D. E. SCHLEIERMACHER . On Religion: Speeches to its Cultured Despisers, p. 5.

${ }^{31}$ Friedrich D. E. SCHLEIERMACHER. On Religion: Speeches to its Cultured Despisers, p. 6.

${ }^{32}$ Friedrich D. E. SCHLEIERMACHER . On Religion: Speeches to its Cultured Despisers, p. 6.

${ }^{33}$ Friedrich D. E. SCHLEIERMACHER. On Religion: Speeches to its Cultured Despisers, p. 6.

${ }^{34}$ Friedrich D. E. SCHLEIERMACHER. On Religion: Speeches to its Cultured Despisers, p. 7. 
também não deixa de ser, a harmonia que supera todas as oposições, ou seja, a harmonia comparável à essência da religião.

Debaixo das polaridades schleiermacherianas que caracterizam a vida humana há um fundamento que encontra e une os opostos. Este fundamento não é definido de um ponto de vista estritamente conceitual. Ele atua como uma espécie de pressentimento de que há uma unidade percebida através da perspectiva que parte de uma posição singular no Todo. Esta posição específica se dá sempre no meio de dois extremos, não podendo dominá-los e nem superá-los.

Em todo objeto para o qual Schleiermacher pendeu, ele tentou descobrir o significado e as implicações da nova percepção do dinâmico jogo mútuo entre o eu e o mundo, entre a universalidade e particularidade, entre a unidade e caos. Ele trabalhou nesta tarefa com a convicção de que os seres humanos estão ancorados no meio, aptos a sentir um pólo absoluto em cada lado e impelidos na direção de um ou outro, mas inaptos para agarrar firmemente a cada pólo ou para emergir acima das polaridades para ver e entender a origem e o objetivo de todas as coisas ${ }^{35}$.

Tanto o conceito de ironia quanto a concepção da vida do Todo se fundamentam sob a égide da oposição, do conflito irreconciliável entre opostos. Se para Schlegel o homem, com a ajuda do ego, consegue perceber as mais variadas combinações entre pólos distintos; para Schleiermacher é a religião que acompanha o homem em sua tentativa de harmonizar as oposições.

Como podemos notar, há uma confluência de temas e interesses entre ambos os autores em um aspecto fundamental de seus respectivos pensamentos, a saber, a relação entre mundo, homem e algo que os transcende. O conceito de romantische Poesie, inaugurado por Schlegel, fez com que a busca por uma unidade orgânica transcendesse os aspectos literários e se alargasse mais e mais, abarcando a relação entre o homem e as realidades que o cercam. Neste ponto, o conceito de ironia e a concepção de vida do Todo nos fornecem mecanismos de percepção da tarefa interminável do homem, isto é, a busca pelo infinito, pela harmonia com o Todo. Por mais que o indivíduo anseie superar sua situação dual de forma singular e criativa, sua consciência de estar limitado a este mundo deve estar sempre aguçada.

Agora uma questão se impõe: Seria essa aproximação entre Schlegel e Schleiermacher suficiente para identificar este último como um autor tipicamente romântico?

35 Jack FORSTMAN. A Romantic Triangle: Schleiermacher and Early German Romanticism, p. 95-96. 
A preocupação agora, portanto, será a de nos aproximarmos o quanto possível de uma possibilidade de resposta, que indicará se Schleiermacher passou por uma fase romântica em Berlim - como se houvesse vivido uma fase específica de seu pensamento - ou se ele pode ser considerado um membro nuclear do movimento romântico, principalmente em seus momentos iniciais.

\section{SCHLEIERMACHER E O ROMANTISMO: APONTAMENTOS DE UMA MÚTUA CONTRIBUIÇÃO}

Uma das portas de entrada para a discussão da contribuição de Schleiermacher ao romantismo e da influência deste movimento sobre nosso autor é a questão da linguagem. Segundo Walzel, Schleiermacher tinha uma habilidade tipicamente romântica de compreensão da religião ${ }^{36}$. Ora, acreditamos que muito disso se deve ao fato de que a linguagem utilizada por Schleiermacher era tipicamente romântica.

Compreende-se, desde já, que a religião precisa ser expressa, contudo, ela possui uma forma particular de comunicação [Mitteilung], pois pertence a um tipo próprio de comunidade $^{37}$. Segundo Hendrikus Berkhof, o objetivo fulcral de Schleiermacher nos Discursos é exprimir o evangelho utilizando-se da linguagem emotiva do romantismo ${ }^{38}$. Mas porque Schleiermacher faz uso de tal linguagem? Ora, Schleiermacher tentou expor as origens da religião através da nova concepção de mundo que ele compartilhava com os primeiros românticos. Esta nova visão de mundo era avessa à linguagem sistêmica das filosofias fundacionais. Desta forma, a linguagem romântica coadunava-se bem mais com a preocupação de não encerrar a religião exclusivamente em um conceito.

O desiderato schleiermacheriano era o apontar, o indicar o lugar no qual a religião é ela mesma. Eric Sean Nelson caracteriza esse empreendimento schleiermacheriano através do conceito de "hermenêutica indicativa": "Para Schleiermacher, a linguagem não é esgotada na referência, mas abre-se na expressão, indicação, execução e sugestão. Nos Discursos e nos

\footnotetext{
36 Oskar WALZEL. German Romanticism, p. 13

${ }^{37}$ Eric S. NELSON. Schleiermacher and Romanticism: Holism, Singularity, and the Unconditional. In: Hans DIERKES; Terrence N. TICE ; Wolfgang VIRMOND. (Ed.). Schleiermacher, Criticism and the Critical Arts: A Festschrift in Honor of Hermann Patsch. Lewiston; Queenston; Lampeter: The Edwin Mellen Press, 2008, p. 100.

${ }^{38}$ Hendrikus BERKHOF. Two Hundred Years of Theology: Report of a Personal Journey. Trad: Jon Vriend. Michigan: Grand Rapids, 1992, p. 37.
} 
Monólogos, Schleiermacher desenvolveu uma linguagem de indicação (Andeutung) e enfatizou o acesso indireto àquilo que não pode ser diretamente referido ou dito" ${ }^{\text {39 }}$.

Se há, pois, um romantismo em Schleiermacher, ele deve ser interpretado como um interesse pelo singular e pelo Todo, que é sugerido na experiência e indicado na linguagem e que, portanto, escapa do conhecimento sistemático ${ }^{40}$. A comunicação da qual falamos é ética, na medida em que institui a mediação entre os indivíduos de uma comunidade, e já é ligada ao inefável, isto é, ao infinito. Segundo Nelson, Schleiermacher sugeriu nos Discursos que “[...] a comunicação emerge enquanto uma necessidade da nossa experiência dos vestígios do infinito e do inefável, em nossa experiência não-representacional [...]" ${ }^{\prime 1}$. A comunicação aqui não é uma simples transmissão. Ela é aquilo que liga a individualidade do remetente individualidade que tem seu papel elevado no romantismo através da promoção da irredutibilidade da experiência individual - à universalidade do destinatário.

Martin Redeker afirma que Schleiermacher foi, sem dúvida, um membro do círculo romântico, mas manteve certa independência. Redeker concorda com o fato de que Schleiermacher viveu no mundo dos românticos e falou a linguagem destes, mas é contrário aos que afirmam que todas as principais concepções do autor são frutos do seu período inicial em Berlim. Pode-se citar como exemplo a valorização do aspecto individual do ser humano, que tem origem na herança moraviana de Schleiermacher ${ }^{42}$.

Visto que uma equívoca compreensão do romantismo lança, freqüentemente, conotações pejorativas sobre o movimento, não é comum o uso do termo "romântico" para nomear o pensamento do jovem Schleiermacher. Para alguns críticos, o romantismo é “subjetivismo poético"; um poetizar e sentimentalizar da vida religiosa ${ }^{43}$. Contudo, Redeker nos aponta a verdadeira natureza da principal obra romântica de Schleiermacher: "Os Discursos não são um livro acadêmico. Ele é destinado a não-teólogos, os 'cultos desprezadores da religião'. Estilisticamente o livro não é nem um sermão e nem um exame filosófico, mas antes uma típica realização literária no espírito da era romântica" ${ }^{44}$.

Uma leitura recente de Philip Clayton busca deixar falar os tons românticos da obra de Schleiermacher. Seu interesse, portanto, não é analisar um conceito específico de

\footnotetext{
${ }^{39}$ Eric S. NELSON. Schleiermacher and Romanticism: Holism, Singularity, and the Unconditional, p. 107.

${ }^{40}$ Eric S. NELSON. Schleiermacher and Romanticism: Holism, Singularity, and the Unconditional, p. 99.

${ }^{41}$ Eric S. NELSON. Schleiermacher and Romanticism: Holism, Singularity, and the Unconditional, p. 107.

42 Martin REDEKER. Schleiermacher: Life and Thought, p. 33.

${ }^{43}$ Martin REDEKER. Schleiermacher: Life and Thought, p. 30.

${ }^{44}$ Martin REDEKER. Schleiermacher: Life and Thought, p. 34-35.
} 
romantismo e avaliar se Schleiermacher se encaixa ou não em tal definição. Antes, ele oferece a leitura romântica como uma das chaves de compreensão da obra de Schleiermacher ${ }^{45}$. O individual é abraçado pelo infinito. O Todo é anterior às partes e as contagia totalmente, “[...] criando nossa conexão com todas as coisas vivas e com o universo como um todo" ${ }^{46}$. A sensibilidade romântica de Schleiermacher contribuiu para evitar um perigo que sempre apareceu diante de Spinoza, qual seja, "[...] que o indivíduo se tornasse um mero modo ou uma parte permutável dentro do Todo. Visto que o sentimento do individual e da liberdade é irredutível, seu lugar dentro do todo nunca pode ser preenchido por qualquer outro"47. Segundo Clayton, Schleiermacher está em consonância com diversos aspectos românticos, como por exemplo, a irredutibilidade das expressões individuais, bem como o processo orgânico de relação entre Deus, homem e mundo, fundamental tanto para o romantismo quanto para o próprio Schleiermacher.

Segundo Walzel, o impacto causado pelos Discursos foi tão marcante na cultura romântica que apenas uma mente muito perspicaz pode diferenciar a contribuição de Schleiermacher daquela de Schlegel. Assim, a partir dos Discursos "[...] o problema do infinito e do universo foi de importância primária para os românticos. Este foi o ponto de partida para as tentativas de colocar o homem e a infinidade em íntima aliança. Schleiermacher indicou uma das formas pelas quais, no sentido romântico, o absoluto tornouse acessível ao homem ${ }^{48}$ ". Isto significa dizer que as diretrizes fundamentais ou as críticas das concepções românticas de religião tinham como aporte os Discursos de Schleiermacher. Segundo Forstman, a resposta dos "menosprezadores eruditos" aos Discursos foi variada: Fichte e Schelling acharam o livro difícil de compreender, este último, contudo, reviu sua opinião em 1801. Henriette Herz e Dorothea Veit foram simpáticas ao livro. Goethe apreciou a "cultura e a versatilidade" 49 do autor, mas pensou que o estilo da parte final era pobre e o todo muito cristão. Já Novalis e Schlegel receberam a obra de forma entusiasmada.

Concluindo, pode-se afirmar que a relação de Schleiermacher com o romantismo se deu em um âmbito de contribuição mútua. Seria um erro nomearmos Schleiermacher um "romântico", caso se considerasse que sua contribuição ao movimento fosse apenas uma

\footnotetext{
${ }^{45}$ Philip CLAYTON. Schleiermacher as Romantic: Joyful Experience, the Individual, and the Whole. In: Hans DIERKES; Terrence N. TICE ; Wolfgang VIRMOND. (Ed.). Schleiermacher, Criticism and the Critical Arts: A Festschrift in Honor of Hermann Patsch, p. 115.

${ }^{46}$ Philip CLAYTON. Schleiermacher as Romantic: Joyful Experience, the Individual, and the Whole, p. 121.

${ }^{47}$ Philip CLAYTON. Schleiermacher as Romantic: Joyful Experience, the Individual, and the Whole, p. 121.

${ }^{48}$ Oskar WALZEL. German Romanticism, p. 51.

${ }^{49}$ Jack FORSTMAN. A Romantic Triangle: Schleiermacher and Early German Romanticism, p. 81.
} 
simples repetição de concepções já descobertas por outras figuras do movimento. Schleiermacher é uma das figuras chave do movimento em seu sentido mais genuíno, pois conseguiu adequar suas próprias concepções (imaginação, sentimento, intuição, valorização da arte etc.) a uma nova visão de mundo capitaneada pelo círculo de Berlim. Como visto, muitas das concepções difundidas na Frühromantik já eram familiares a Schleiermacher antes mesmo de sua chegada ao círculo romântico, mas Schleiermacher pôde dar sua marca própria ao romantismo principalmente no campo da religião, mesmo escrevendo os Discursos em íntima relação com os primeiros românticos.

\section{REFERÊENCIAS}

BEISER, Frederick C. The Romantic Imperative: The Concept of Early German Romanticism. Cambridge, Massachusetts; London: Harvard University Press, 2003

BERKHOF, Hendrikus. Two Hundred Years of Theology: Report of a Personal Journey. Trad: Jon Vriend. Michigan: Grand Rapids, 1992.

CLAYTON, Philip. Schleiermacher as Romantic: Joyful Experience, the Individual, and the Whole. In: Hans DIERKES; Terrence N. TICE ; Wolfgang VIRMOND. (Ed.). Schleiermacher, Criticism and the Critical Arts: A Festschrift in Honor of Hermann Patsch, p. 115-124.

CRAWFORD, Alexander W. The Philosophy of F.H. Jacobi. London: Macmillan \& Co, 1905.

CROUTER, Richard. Introduction. In: Friedrich Schleiermacher. On Religion: Speeches to its Cultured Despisers. Cambridge University Press. 1988, p. xi-xxxix.

DREHER, Luis Henrique. Metaphors of light: Philipp K. Marheineke's Method and the Ongoing Program of Mediation Theology. Bern; Berlin; Frankfurt/M; New York; Paris; Wien: Peter Lang, 1998.

FORSTMAN, Jack. A Romantic Triangle: Schleiermacher and Early German Romanticism. Montana: Scholars Press, 1977

FRANK, Manfred. The Philosophical Foundations of Early German Romanticism. Trad: Elizabeth Millán-Zaibert. New York: State University of New York Press, [s.d].

LOVEJOY, Arthur O. On the Meaning of 'Romantic' in Early German Romanticism. Modern Language Notes. The Johns Hopkins University Press, vol. 31, n. 7, 1916, p. 385396. 
NELSON, Eric S. Schleiermacher and Romanticism: Holism, Singularity, and the Unconditional. In: Hans DIERKES; Terrence N. TICE ; Wolfgang VIRMOND. (Ed.). Schleiermacher, Criticism and the Critical Arts: A Festschrift in Honor of Hermann Patsch. Lewiston; Queenston; Lampeter: The Edwin Mellen Press, 2008, p. 99-114.

REDEKER, Martin. Schleiermacher: Life and Thought. Trad: John Wallhauser. Philadelphia: Fortress Press, 1973.

SCHELLING, Friedrich. Investigações filosóficas sobre a essência da liberdade humana e os assuntos com ela relacionados. Trad: Carlos Morujão. Lisboa: Edições 70, 1993.

SCHLEGEL, Friedrich. Philosophical Fragments. Trad: Peter Firchow. Minneapolis; London: University of Minnesota Press, 1998.

SCHLEIERMACHER, Friedrich D. E. On Religion: Speeches to its Cultured Despisers. Trad: Richard Crouter. Cambridge: Press Syndicate of the University of Cambridge, 1996.

WALZEL, Oskar. German Romanticism. Trad: Alma Elise Lussky. New York: Capricon Books, 1966. 